\title{
EKSISTENSI BISNIS TEMBAKAU DI MASA PANDEMI COVID-19 DI UD AL-MUSTHOFA
}

\author{
Neli Hajar ${ }^{1}$, Supriyanto ${ }^{2}$, Ahmad Syaifudin ${ }^{3}$ \\ ${ }^{123}$ Universitas Selamat Sri, Kendal, Indonesia \\ Email: meronapagi@gmail.com
}

\begin{abstract}
With the development of time in establishing a business, of course there are many challenges that must be faced and anticipated, one of which is competition. Business competition here, companies or business people are required to be more intensive in facing increasingly fierce competition. Business competition faced by entrepreneurs or business people does not only involve on a local basis but also involves business actors. The competition during the Covid 19 pandemic was no exception, which had a tremendous impact, thus hampering various areas of life. One of the sectors most affected is the economic sector. Competition in the business world as a benchmark in creating better and more valuable products, competition is a developmental stage of a cultural phenomenon that inevitably has to be passed, the most important thing is how to respond and prepare for the face because it is not easy to compete with other products, business actors are challenged to be more competitive strategically by increasing their ability to compete in domestic competition and also increasing their ability to compete professionally, with the right strategy that must be applied to ensure success through exploiting existing opportunities, one of them. The tobacco business is a very promising business, even though there are many challenges, but the tobacco business is able to survive the competition even during the Covid 19 pandemic.Of course, by creating innovations, creative ideas and loyalty to consumers are things that must be prioritized in order to be able to compete with actors. other businesses, in order for the survival of a tobacco business to survive and not be eroded by competition, this business actor has much to deal with, of course by creating solutions to overcome the problem of competition in the business itself, because tobacco is one of the most important agricultural commodities. high value.
\end{abstract}

Keywords: the Covid-19 pandemic, business competition, tobacco

\section{PENDAHULUAN}

Dalam kehidupan sehari-hari perhatikan jutaan orang melakukan kegiatan bisnis. Mereka ada yang berhasil mengembangkan usaha dan memperbesar nilai bisnisnya yang makin lama makin maju tetapi ada pula yang gagal, bagi mereka yang berhasil, kegiatan bisnis makin menarik dalam kehidupan mereka (Buchari Alma, 2018). Bisnis harus berpandangan jauh kedepan, bisnsi didirikan bukan untuk sementara tetapi untuk selamanya, seumur hidup pemilik dan terus dilanjutkan oleh ahli warisnya, oleh sebab itu, dunia bisnis harus menjaga faktor kontinuitas usaha yang membuat landasan usaha yang kuat menuju masa depan yang penuh tantangan (Kotler, et.al, 2004). Bisnis adalah suatu kegiatan usaha individu yang terorganisasi untuk menghasilkan dan menjual barang dan jasa guna medapatkan keuntungan dalam memenuhi kebutuhan masyarakat, secara umum kegiatan ini ada di dalam masyarakat dan ada di dalam industri (Bakhri, et.al, 2018). 
Dengan perkembangannya waktu dalam mendirikan suatu bisnis tentunya banyak tantangan-tantangan yang harus dihadapi dan diantisispasi salah satunya persaingan. Persaingan bisnis disini perusahaan atau pelaku bisnis di tuntut untuk lebih intensif dalam menghadapi persaingan yang semakin ketat. Persaingan bisnis yang dihadapi oleh pengusaha atau pelaku bisnis tidak hanya melibatkan pada dasar lokal saja akan tetapi juga melibatkan para pelaku usaha. Persaingan dalam dunia bisnis sebagai tolak ukur dalam menciptakan produk yang lebih baik dan bernilai lebih, persaingan merupakan suatu tahapan perkembangan fenomena budaya yang mau tidak mau harus dilalui yang terpenting adalah bagaimana menyikapi dan mempersiapkan diri dalam mengahadapi karena tidak mudah akan bersaing dengan produk yang lain, pelaku usaha ditantang untuk menjadi lebih bersaing secara strategi dengan menigkatkan kemampuan untuk persaingan domestik dan ikut pula meningkatkan kemampuan bersaing secara profesional, dengan strategi yang tepat yang harus diaplikasikan untuk mersih keberhasilan melalui pemanfaatan peluang-peluang yang ada salah satunya.

Bisnis Tembakau merupakan bisnis yang sangat menjanjikan walaupun tantangantantangan akan tetapi bisnis tembakau mampu bertahan dalam menghadapi persaingan tentunya dengan menciptakan inovasi, ide kreatif dan loyalitas kepada konsumen menjadi hal yang harus diutamakan agar mampu bersaing dengan pelaku bisnis yang lainnya, agar kelangsungan hidup sebuah bisnis tembakau tetap bertahan dan tidak tergerus persaingan, banyak yang harus dihadapi para pelaku bisnis ini, tentunya dengan menciptakan solusisolusi untuk mengatasi masalah persaingan dalam bisnis itu sendiri, karena tembakau merupakan salah satu komoditas pertanian yang sangat bernilai tinggi.

\section{KERANGKA TEORITIS}

\subsection{Masa Pandemi Covid 19}

Pandemi Covid 19 merupakan bencana non alam yang memiliki dampak luar biasa, sehingga menghambat berbagai bidang kehidupan, seperti sosial, ekonomi, kesehatan, psikologis. Salah satu sektor yang paling terdampak adalah sektor ekonomi karena kerentanan sosial menjadikan posisi ketahanan ekonomi mengalami guncangan. Ketahanan ekonomi diartikan sebagai kondisi dinamik kehidupan perekonomian bangsa yang berisi keuletan dan ketangguhan yang mengandung kemampuan untuk mengembangkan kekuatan nasional dalam menghadapi serta mengatasi segala ancaman, gangguan, hambatan, dan tantangan yang dating dari luar maupun dari dalam negeri yang langsung maupun tidak langsung untuk menjamin kelangsungan hidup perekonomian (Marlinah, 2017).

\subsection{Eksistensi Bisnis}

Bisnis adalah seluruh kegiatan yang diorganisasikan oleh orang-orang yang berkecimpung dalam bidang perniagaan dan industri yang menyediakan barang dan jasa untuk kebutuhan mempertahankan dan memperbaiki standar serta kualitas hidup mereka (Husein Umar, 2005). Faktor-faktor kontuniutas bisnis adalah (1). Likuiditas yaitu kemampuan bisnis membayar hutang pada saat jatuh tempo, likuiditas juga berarti mampu menjaga kelancaran proses produk produksi, (2). Solvabilitas, yaitu berusaha agar modal sendiri (assets) binis lebih besar dari hutangnya. (3). Soliditas, yaitu kemampuan bisnis, untuk memperoleh kepercayaan dari masyarakat, kepercayaan meliputi moral pengelola bisnis, tepat dalam berjanji dan dipercaya dalam bidang keuangan. (4). Rentabilitas, yaitu bisnis mampu memperoleh keuntungan yang layak tidak merugi (Santoso, et.al, 2020). (5). Credit wour dighed, yaitu bisnis dipercaya sehingga layak memperoleh kredit atau pinjaman (Buchari Alma, 2009). Jika kelima faktor terjaga maka bisnis yang dijalankan 
akan berkembang secara meyakinkan. Bisnis diartikan sebagai aktivitas terpadu, meliputi pertukaran barang dan jasa atau uang yang dilakukan oleh dua (2) pihak atau lebih dengan maksud memperoleh manfaat atau keuntungan dalam perkembanganya bisnis tidak hanya dioperasikan untuk mencapai keuntungan semata, melainkan berkepintangan untuk menjaga kelangsungan hidup sumber daya atau bertanggung jawab terhadap linkungan sosial dan memberdayakan etika dalam bisnis dan perlu dikelola secara efektif dan efisien dalam mencapai tujuan dalam bisnis.

\subsection{Bisnis Tembakau}

Dalam bahasa Indonesia Tembakau adalah sejenis pipa berbentuk Y untuk menghirup asap tembakau atau mengacu pada gulungan daun-daun pada tembakau, tembakau telah lama digunakan sebagai etheogen di Amerika, dalam perkembanganya tembakau mengalami perubahan dalam permintaan dan tenaga kerja yang menyebabkan perkembangan industri pokok di Indonesia semakin pesat. Tembakau adalah hasil bumi yang diproses dari tanaman yang juga dinamai sama, tanaman tembakau terutama mengandung nikotin tabalum dana nikotin rustica. Tembakau merupakan produk pertanian semusim yang bukan termasuk komiditas pangan, melainkan komoditas perkebunan. Produk dari tembakau sebagai bahan baku Rokok dan cerutu tembakau, tembakau juga dapat dikunyah, kandungan metabolit yang kaya juga membuat bermanfaat sebagai bahan baku obat. Tembakau produk yang sangat sensitif terhadap cara lokasi tanam, budidaya, daerah, cuaca atau iklim dan dalam cara pengelolaanya, akibatnya macam-macam produk tembakau biasanya dinamai sesuai lokasi tanam

\section{METODE PENELITIAN}

Adapun metode yang digunakan dalam penulisan jurnal ini yaitu metode pengumpulan data yang digunakan dalam penulisan ini adalah Riset kepustakaan, melakukan peninjauan pustaka dari berbagai literatur karya ilmiah, majalah dan buku-buku yang menyangkut teori-teori yang dibahas dan riset lapangan, yang dilakukan langsung di lokasi tempat penelitian yaitu di UD. Al-Musthofa.

\section{HASIL PENELITIAN DAN PEMBAHASAN}

Bisnis pada umumnya ditekankan pada 3 hal diantaranya Usaha-usaha perorangan kecil-kecilan dalam bidang barang dan jasa, Usaha perusahaan besar seperti pabrik, transport, perusahaan, dan sebagainya, dan Usaha dalam bidang struktur ekonomi suatu bangsa. Ada beberapa taktik bisnis tentang cara agar bisnis yang dirintis bisa terus eksis ditengah persaingan yang ada menurut Zakaria danujatmiko diantaranya fokus pada perkembangan usaha, perluas jaringan, ikuti perkembangan pasar, dan amati gerak pesaing.

Tembakau merupakan produk pertanian semusim yang bukan termasuk komiditas pangan, melainkan komoditas perkebunan. Kualitas tembakau sangat ditentukan agar menghasilkan tembakau terbaik salah satunya tembakau Weleri. Tembakau tersebut dibentuk rajangan dan lalu dikirim kepabrik-pabrik. Salah satunya bisnis tembakau di UD. Al-Musthofa yang berjalan hampir 45 tahun yang lalu dan menyediakan atau memproduksi dari tembakau meliputi : (1) Tembakau rajangan kering, (2) Tembakau dendeng (lembaranlembaran), dan (3) tembakau kritik.

Bisnis tembakau sendiri sangat kuat dan selalu tangguh dalam menghadapi berbagai masalah dalam persaingan, tembakau merupakan tanaman yang menguntungkan tembakau menjadi salah satu komiditas di dalam bisnis perkebuna, sebagai bahan utama pembuatan rokok, cerutu, dan sebagainya. Harga jual rokok yan semakin mahal membuat tembakau menjadi salah satu yang dicari. Bisnis tembakau di Indonesia sangat kuat karena setia 
tahun target tercapai da dalam bisnis ini kita harus mengetahui kegiatan bisnis itu sendiri (Mukhtar, 2013).

Dalam menjalankan kegiatan bisnis maka harus mampu mengombinasikan empat macam sumber yaitu : material, human, financial, dan informasi. Bahwa untuk dapat menyediakan barag dan jas bagi kebutuhan masyarakat, diperlukan lebih dulu bahan mentahnya, kemudian diproses dalam pabrik menjadi hasil produksi dengan demikian bahwa fungsi dasar bisnis adalah Al quiring row materials (mencari bahan mentah), Manufacturing row materials into product (merubah bahan mentah menjadi produk), dan distributing products to consumer (menyalurkan barang ketangan konsumen).

Dalam menghadapi persaingan atau kompetisi antar para penjual yang sama-sama berusaha mendapatkan keuntungan, pangsa pasar, dan jumlah penjualan, dalam berbagai teori ekonomi persaingan dalam suatu pasar dibedakan menjadi berbagai macam persaingan yaitu persaingan sempurna dan persainga tidak sempurna, persaingan juga dapat membedakan harga produk, distribusi, dan promosi, dan tantangan-tantangan makin lama makin meningkat. Sehingga UD. Al-Musthofa menekankan pada bisnis tembakau harus punya stok bahan baku yang cukup, harus selalu bertahan dalam menghadapi maslah harga agar bisa bersaing, dalam hal keuntungan atau laba secukupnya yang penting bisnis tetap berjalan, dan harus selalu bertahan dalam bersaing, dalam hal pemasaran atau promosi.

Jalannya suatu usaha tidak lepas dengan adanya tantangan-tantangan bisnis. Dilihat dari beberapa aspek lain tantang bisnis yang akan datang tantangan tersebut antara lain (1). The Demographic and Cultural Challenge, yaitu menyangkut pertambahan penduduk dan struktur usia penduduk saai ini dan masa yang akan datang, dunia bisnis harus memperhitungkan masalah ini, (2). The Environmental Challenge, yaitu Tantangan lingkungan terutama menyangkut masalah polusi, air, udara, suara yang mempunyai efek terhadap penyakit, (3). The Social Responsibility and Ethes Challenge, yaitu dunia bisnis dihadapkan pada tanggung jawab terhadap masyarakat, pertama proses produksi harus selalu menjaga kelestarian lingkungan, kemudian produk yang dihasilkan harus bermanfaat bagi konsumen, (4). The Technology Challenge, yaitu hasil perkembangan ilmu pengetahuan yang membuat proses produksi makin lama makin canggih. Dunia bisnis pengeluaran banyak untuk melakukan penelitian terhadap kemiskinan perkembangan teknologi baru (Bakhri, et.al, 2018).

Agar bisnis tembakau tetap bertahan dalam persaingan, tantangan ini timbul juga dikarenakan (1). Tantangan Produktivitas, yaitu dunia bisnis harus meningkatkan produktivitasnya, karena mereka akan menghadapi pasar luas yang semakin berkembang, usaha meningkatkan produktivitas ini dapat dilakukan dengan cara memperbaharui mesinmesin dengan mesin modern, canggih agar hasil produksinya tidak ketinggalan zaman dan efisien dalam melakukan produksi. Kembangkan kegiatan research dan development, sediakan dana untuk itu, agar bisa berkembang desain, mutu dan pasar baru dari produk yang dihasilkan. Kembangkan manajemen personalia agar karyawan dapat dimotivasi dalam meningkatkan produksi dan moralnya lebih baik. Libatkan karyawan dalam pengambilan keputusan. (2). Tantangan Kualitas, yaitu Konsumen, merasa tidak senang membeli produk yang cepat rusak meningkatkan mutu berarti membuat sesuatu menjadi lebih baik dan tingkat efisien pun menjadi lebih baik pula perbaikan kualitas ini meyangkut produk saja, namun juga mencakup seluruh bagian dan tingkatkan dalam perusahaan. (3). Tantangan Pasar Global, yaitu Persaingan global makin lama makin meningkat, oleh sebab itu produktivitas dan kualitas produk harus ditingkatkan agar dapat menghadapi persaingan global tersebut. Dalam tantangan-tantangan bisnis, tentunya para pelaku bisnis harus 
mampu menghadapi berbagai persaingan dan tidak lepas dari tantangn tentunya ada peluang-peluang bisnis.

\section{PENUTUP}

Pandemi Covid 19 merupakan bencana non alam yang memiliki dampak luar biasa, sehingga menghambat berbagai bidang kehidupan, Salah satu sektor yang paling terdampak adalah sektor ekonomi pada Bisnis Tembakau, walaupun banyak tantangantantangan tetapi bisnis tembakau akan mampu bertahan dalam menghadapi persaingan sekalipun pada saat masa Pandemi Covid 19. tentunya dengan menciptakan inovasi, ide kreatif dan loyalitas kepada konsumen menjadi hal yang harus diutamakan agar mampu bersaing dengan pelaku bisnis yang lainnya, karena tembakau merupakan salah satu komiditas pertanian yang sangat bernilai tinggi, maka agar kelangsungan hidup sebuah bisnis tembakau tetap bertahan dan tidak tergerus persaingan, banyak yang harus dihadapi para pelaku bisnis ini, tentunya dengan menciptakan solusi-solusi untuk mengatasi masalh persaingan dalam bisnis itu sendiri.

\section{DAFTAR PUSTAKA}

Alma, B. (2018). Manajemen Pemasaran dan Pemasaran Jasa. Bandung: Alfabeta.

Alma, B. (2009). Manajemen Pemasaran dan Pemasaran Pasar, Bandung: Alfabeta.

Bakhri, S; Buchori, B; \& Ardi, R. P. (2018). Praktik Pengelolaan SDM Melalui Outsourcing: Konsep Dan Kenyataan. Jurnal Visi Manajemen, 2018, 3.1.

Kotler, P. \& Armstrong, G. (2004). Dasar-dasar Pemasaran, Alih Bahasa: Alexander Sandoro, Jilid Satu, Edisi Kesembilan, Jakarta: PT. Indeks.

Marlinah, L. (2017). Meningkatkan Ketahanan Ekonomi Nasional Melalui Pengembangan Ekonomi Kreatif. Cakrawala-Jurnal Humaniora, 2017, 17.2: 258-265.

Mukhtar. (2013). Metode Praktis Penelitian Deskriptif Kualitatif. Jakarta. Selatan: Referensi (GP Press Group).

Santosa, S., Tho'in, M., \& Sumadi, S. (2020). Analisis Tingkat Kesehatan Bank Syariah Menggunakan Rasio Permodalan, Profitabilitas, Pembiayaan, dan Risiko Kredit. Jurnal Ilmiah Ekonomi Islam, 6(2), 367-371.

Umar, H. (2005), Metode Penelitian Untuk Tesis Dan Bisnis, Jakarta: Grafindo. 